\title{
PENGARUH LAYANAN KONSELING KELOMPOK DENGAN TEKNIK PROBLEM SOLVING UNTUK MENGATASI KONFLIK ANTARA REMAJA YANG MEMILIKI INSECURE ATTACHMENT DENGAN ORANG TUA
}

\author{
Susi Fitri ${ }^{1}$ \\ Aulia Masturah ${ }^{2}$
}

\begin{abstract}
Abstrak
Penelitian ini bertujuan untuk mengetahui pengaruh layanan konseling kelompok dengan teknik problem solving untuk mengatasi konflik antara remaja yang memiliki insecure attachment dengan orang tua. Penelitian ini menggunakan Quasi Experimental dengan bentuk pretest-posttest Nonequivalent Control Grup Design. Teknik pengambilan sampel yang digunakan adalah purposive sampling. Sampel penelitian ini adalah 10 peserta didik dengan skor level intensitas konflik yang tinggi. Sampel penelitian ini dibagi menjadi dua kelompok, yaitu 5 orang dalam kelompok ekperimen dan 5 orang dalam kelompok kontrol. Instrumen yang digunakan dalam penelitian ini adalah relationship styles questionnaire (RSQ) dan issue checklist (IC). Pengujian hipotesis menggunakan teknik Mann Whitney UTest. Hasil pengujian hipotesis menunjukkan bahwa nilai Asymp.sig sebesar 0,008. Nilai probabilitas tersebut lebih kecil dibandingkan nilai signifikansi $\alpha$ (alpha) 0,05 yang digunakan dalam penelitian ini. Dengan demikian dapat disimpulkan bahwa $\mathrm{H}_{0}$ ditolak dan $\mathrm{H}_{1}$ diterima. Berdasarkan hasil penelitian dapat disimpulkan bahwa konseling kelompok dengan teknik problem solving memberikan pengaruh yang signifikan dalam menurunkan skor intensitas konflik antara remaja yang mengalami insecure attachment dengan orang tua.
\end{abstract}

Kata Kunci: Konseling Kelompok, Problem solving, Konflik Orang tua-Remaja, Attachment

\begin{abstract}
This research aims to determine an effect of group counseling with problem solving techniques to solve conflicts between adolescent who have insecure attachment with parent. This research used Quasi-Experimental research design in the form Nonequivalent Control Group Design. Sampling technique used was purposive sampling. The sample of this research were ten students who had high level of conflict intensity score. The sample of this research devided into two groups, that is five students in experimental group dan five students in control group. The instrument used in this research were relationship styles questionnaire (RSQ) and issue checklist (IC) for selecting members of the group. The hypothesis testing used the Mann Whitney U-Test. Hypothesis testing results show that the value Asymp.Sig of 0.008. The probability value is less than the significance value a (alpha) of 0.05 were used in this research. It can be conclude that $H_{0}$ is rejected and $H_{1}$ accepted. Based on the results of this research concluded that the group counseling with
\end{abstract}

\footnotetext{
${ }^{1}$ Universitas Negeri Jakarta, susi.fitri@unj.ac.id

${ }^{2}$ Universitas Negeri Jakarta, auliamasturah04@gmail.com
} 
problem solving techniques has significant effect on decreasing score of intensity

conflict between adolescent who have insecure attachment with parent.

Keywords: Group Counseling, Problem Solving, Parent-adolescent Conflict, Attachment.

\section{PENDAHULUAN}

Masa remaja adalah masa terjadinya banyak perubahan. Salah satu yang menonjol selama masa remaja adalah membangun diri sebagai makhluk yang otonom. Keinginan orang tua untuk mengontrol remaja dan keengganan orang tua untuk memberikan otonomi secara penuh mengakibatkan perilaku yang dianggap mengekang bagi remaja (Ningsih, 2012).

Dalam penelitian Gunn mengamati bahwa konflik meningkat pada masa remaja awal, dengan intensitas tertinggi pada pertengahan masa remaja. Sementara peristiwa konflik setiap harinya meningkat dan mejadi lebih intens, namun waktu yang dihabiskan remaja dengan orangtua mereka menjadi menurun. Sehingga orangtua menganggap bahwa masa remaja merupakan "tahap paling sulit" dari perkembangan remaja-remaja mereka. Peraturan mengenai jam malam, pemilihan teman, pemilihan baju, dan aturan lainnya merupakan salah satu dari terbentuknya konflik antara remaja dan orang tua. (Meichenbaum, Fabiano, \& Fincham, 2002)

Dalam melihat permasalahan remaja, orang tua lebih sering menggunakan pandangannya sendiri dibandingkan dengan pandangan remaja. Pespektif yang dimiliki remaja bertentangan dengan perspektif orang tua, dimana pola pikir remaja lebih konkret dibandingkan dengan pola pikir orang tua (Sillars, Smith, \& Koerner, 2010). Hal ini terbukti dari hasil studi pendahuluan di SMA Bina Dharma, sebanyak 46\% peserta didik mengalami adu argumen dengan orang tua ketika berkonflik. mereka seringkali merasa sedih dan kecewa ketika orang tua tidak memahami apa yang mereka rasakan dan inginkan, hal ini terlihat dengan prosentase $75 \%$ peserta didik mengatakan hal tersebut, dan sebanyak $49 \%$ peserta didik mengatakan bahwa orang tua merespon keinginan-keinginan mereka dengan kritik dan rasa marah.

Selain itu, hubungan orang tua dan remaja berhubungan pula dengan sistem kelekatan mereka. Kelekatan merupakan ikatan antara individu dengan figur kelekatannya. Kelekatan juga merupakan kebutuhan akan rasa aman dan nyaman. Dalam kelekatan, terdapat pola kelekaan yang akan mempengaruhi perilaku individu. Pola kelekatan yang dibangun orang tua pada masa bayi, dan akan mempengaruhi perilaku interpersonal seseorang sepanjang masa. Dalam pola kelekatan terdapat pola kelekatan organized dan disorganized, dimana organized attachment ini memiliki tiga pola kelekatan yaitu secure attachment, insecure-avoidant attachment, dan inscecure-ambivalent attachment. Dan pada disorganized attachment, terdapat pola kelekatan disoriented/disorganized attachment (Prior \& Glaser, 2006).

Menurut Santrock (2011), Remaja yang mengalami insecure-avoidant pada orang tua, mereka cenderung akan mengurangi kontak yang intens terhadap orang tua, dan remaja akan cenderung menjadi agresif dan bahkan akan menimbulkan perilaku kekerasan. Dalam situasi konflik, remaja yang mengalami pola kelekatan ini cenderung akan menanggapinya secara agresif.

Remaja yang mengalami pola kelekatan insecure-ambivalent akan memiliki keinginan antara ingin mendapatkan rasa aman dari orang tua namun mereka memiliki kebutuhan untuk melepaskan diri, dan kebutuhan ini sulit mereka satukan. Remaja yang memiliki pola kelekatan seperti ini cenderung akan memiliki anggapan bahwa orang tua akan mencoba untuk menahan mereka untuk bereksplorasi. Remaja yang memiliki pola kelekatan ini mencoba untuk bergabung dalam kelompok teman 
sebayanya, namun sayangnya mereka akan sering di olok-olok karena "ketergantungan" mereka. Remaja ini akan setengah hati dalam bergabung disebuah kelompok teman sebayanya, karena mereka juga memiliki keinginan untuk menghabiskan waktu bersama orang tuanya (Hughes, Bomber, \& Brisch, K. H., \& Perry, 2009).

Hal ini yang seringkali menjadi masalah karena tidak adanya peran orang tua dalam mendengarkan dan menjalin komunikasi dengan remajanya. Kurang responsif nya orang tua yang mengakibatkan remaja menarik diri dan membuat remaja menjadi tidak nyaman. Berdasarkan hasil studi pendahuluan menunjukkan bahwa prosentase $70 \%$ yang menyatakan bahwa mereka lebih memilih menghindar atau diam daripada harus beragumen dengan orang tua. Disisi lain, sebanyak $82 \%$ peserta didik ingin orang tua mereka selalu hadir dan responsif.

Problem solving atau yang biasa kita katakan sebagai bentuk penyelesaian masalah merupakan suatu interaksi yang bersifat komplek, baik dari segi kognitif, afektif, dan perilaku. Menurut Jaffee dan D'Zurilla (2003) bahwa remaja dengan kemampuan penyelesaian masalah yang baik mampu merespon lebih adaptif dan tepat terhadap situasi dibandingkan dengan remaja yang memiliki kemampuan penyelesaian masalah yang kurang baik. Begitu juga diasumsikan bahwa orang tua yang memiliki kemampuan menyelesaikan masalah lebih baik akan lebih mampu menangani remaja mereka dan mampu membantu remaja-remaja mereka berhasil menyelesaikan masalah secara nyata.

Bimbingan dan konseling memiliki layanan yang bertujuan untuk membantu individu dalam menyelesaikan masalahnya, layanan tersebut adalah konseling kelompok. Sehubungan dengan hal tersebut, konseling kelompok dapat dijadikan sebagai sarana untuk membantu peserta didik menghadapi krisis situasional dan konflik, berjuang dengan masalah-masalah kehidupan pribadi atau antar pribadi, mengalami kesulitan dengan transisi kehidupan, atau mencoba mengubah tingkah laku yang merusak diri sendiri (Corey, 2012).

Terapi pemecahan masalah dengan layanan konseling kelompok dirancang untuk membantu individu mengatasinya lebih efektif dengan masalah kehidupan yang penuh dengan tekanan dan dapat mengurangi kesulitan secara psikologis dan emosional, serta dapat meningkatkan kualitas hidup seseorang. Diharapkan, peserta didik dapat mempelajari cara pemecahan masalah dan menerapkannya ketika mengalami konflik dengan orang tua sehingga intensitas konflik dapat berkurang.

\section{Konflik Orang tua - Remaja}

Masa remaja adalah masa terjadinya banyak perubahan. Salah satu yang menonjol selama masa remaja adalah membangun diri sebagai makhluk yang otonom. Keinginan orang tua untuk mengontrol remaja dan keengganan orang tua untuk memberikan otonomi secara penuh mengakibatkan perilaku yang dianggap mengekang bagi remaja (Ningsih, 2012).

Keinginan remaja untuk mandiri dan menerima teman sebaya yang akhirnya mereka menyesuaikan diri dengan norma dan pengaruh teman sebaya memuat remaja cenderung menolak dan menentang arahan orangtua atau otoritas orang dewasa. Pada saat yang sama, ketika remaja mencari otonomi mereka, banyak orang tua kesulitan dalam melepaskan kontrolnya. Hal ini mengakibatkan jalur komunikasi orangtuaremaja berpotensi menjadi buruk dan mengakibatkan konflik (Meichenbaum et al., 2002).

Janis dan Mann (Chatjoulis \& Humphreys, 2007) berpendapat bahwa individu yang mengalami konflik biasanya akan menggunakan sistem mekanisme pertahanan seperti penghindaran, penolakan, dan serangkaian strategi untuk menghindari stress.

Robin dan Foster mengungkapkan, anak-anak yang dulunya 
diam, sekarang ketika remaja mampu menyajikan sebuah argumen yang logis kepada orang tuanya. Penguatan dari teman sebaya mempengaruhi dan mungkin akan menentang konsekuensi yang diberikan orang tua (Robin \& Foster, 1989).

Menurut Rice dan Dolgin (2005) konflik yang terjadi antara orang tua dan remaja melibatkan lima area konflik yang diperdebatkan. Area tersebut yaitu:

1. Kehidupan sosial; Kehidupan dan kebiasaan sosial remaja mungkin menciptkan banyak konflik dengan orang tua daripada area lainnya. Area tersebut diantaranya: (1) pemilihan teman atau pemilihan pasangan untuk berkencan; (2) seberapa sering remaja diizinkan keluarga untuk kegiatan yang dapat mereka hadiri; (3) peraturan jam malam; (4) pemilihan pakaian dan gaya rambut. Salah satu keluhan yang paling umum dari orang tua adalah bahwa remaja jarang menghabiskan waktu dengan keluarga.

2. Tanggung Jawab; Orang tua mengharapkan remaja untuk menunjukkan tanggung jawabnya dalam hal-hal berikut: (1) melakukan tugas keluarga; (2) bagaimana mengatur uang; (3) menjaga barang-barang pribadi dan ruangan mereka; (4) menggunakan fasilitas keluarga; (5) melakukan pekerjaan diluar rumah

3. Sekolah; Perilaku dan sikap remaja ketika disekolah mendapat banyak perhatian dari orang tua. Orang tua khawatir mengenai nilai dan kemampuan remaja apakah remaja melakukan hal yang sesuai dengan potensi remaja. Kebiasaan ketika disekolah, kehadiran, sikap dan perilaku remaja kepada sekolah dan guru juga menjadi perhatian orang tua.

4. Hubungan dengan keluarga; Pada hubungan keluarga, konflik biasanya muncul ketika remaja menunjukkan perilaku yang tidak dewasa. Konflik juga muncul ketika orang tua melihat tingkat hormat remaja yang ditunjukkan kepada orang tua. Pertengkaran dengan kakak/adik dirumah dan usaha otonomi dari keluarga juga termasuk dalam area konflik ini.

5. Aturan sosial; Dalam aturan sosial, orang tua sangat khawatir dengan perilaku sebagai berikut: (1) meminum minuman keras, merokok, dan menggunakan obat-batan terlarang; (2) penggunaan bahasa dan ucapan; (3) perilaku seksual; (4) keluar dari masalah

\section{Kelekatan (Attachment)}

Kelekatan (attachment) memiliki arti yang khusus, baik dari sifat dan orang yang berlaku di dalamnya. menurut teori kelekatan, kelekatan adalah ikatan antara individu dengan figure kelekatannya. Dalam hubungan orang dewasa, orang lain menjadi sosok figure kelekatannya yang bersifat timbal balik, namun berbeda dengan hubungan antara anak dan orangtua (Prior \& Glaser, 2006)

Dengan melihat perkembangannya, anak membangun akses yang bervariasi yang lebih baik untuk menerima kedekatan, dan belajar memilih salah satu yang paling efektif. Perilaku kelekatan memberikan respon kepada individu untuk melakukan perubahan selama mencoba mencapai tujuannya. Anak mampu mempertimbangkan perubahan perilaku ibunya saat ia berusaha mempertahankan kedekatan dengan dirinya, anak memberikan respon yang efisien yang akan ia ubah sesuai dengan tujuannya (Cassidy, 2016).

Pola-pola kelekatan diklasifikasikan dalam dua cara, salah satunya adala pola tersebut merupakan statregi yang terorganisir (organized) untuk mendapatkan kedekatan attachment ketika sistem perilaku kelekatan diaktifkan, atau kurangnya strategi tersebut yang disebut juga dengan disorganized.

\section{Organized Attachment}

Individu yang memiliki strategi yang terorganisir (organized) untuk mencapai 
tujuannya, dapat dengan aman atau tidak aman melekat pada sosok kelekatan.

\section{Grup B: secure attachment}

Tipe yang khas di Grup B adalah lebih positif dalam tingkah terhadap ibunya daripda grup A dan C. anak lebih harmonis dan kooperatif dalam interaksi dengan ibunya dan lebih mau mematahui permintannya. Anak menggunakan ibu sebagai basis yang aman untuk menjelajahi. Keyakinan ini akan meningkatkan perasaan aman, dan memunginkan individu yang secure untuk menuggukan strategi penyelesaian masalah yang kontruktif dan berfokus pada masalah (Prior \& Glaser, 2006)

2. Grup A:Insecure-Avoidant Attachment

Dalam situasi yang dirasa asing, anak pada grup ini cenderung mempertahaknakan tingkat eksplorasi nya yang relatif tinggi pada pemisahan. Jika anak mendekati ibunya, ia cenderung menunjukkan perilaku cemas dan menghindar. Selain itu, anak yang pada grup ini, dapat diamati dirumah seringkali menangis lebih sering dan menunjukkan kecemasan yang sering pula (Prior \& Glaser, 2006)

3. Grup C: Insecure-resistant/ambivalent attachment

Anak pada grup $\mathrm{C}$ ini biasanya lebih banyak menangis daripada $\mathrm{B}$, baik dirumah maupun di situasi yang asing. Dalam situasi yang asing, anak menanggapi kepergiannya ibunya dengan sebuah tekanan (Prior \& Glaser, 2006). Anak yang berada dalam grup ini pula seringkali gelisah dan pasif, dan cenderung gagal dalam melakukan eksplorasi, dapat meminta berganti kontak dengan tanda penolakan yang marah, tantrum, terlalu kesal. Gagal menemukan suatu kenyamanan dari orang tua (Cassidy, 2016).

Disorganized Attachment

4. Grup D: Dissorganized/disoriented attachment
Terdapat anak yang tidak sesuai dengan grup $\mathrm{A}, \mathrm{B}$, dan $\mathrm{C}$. anak yang berada pada grup ini, mereka tidak memiliki pola perilaku yang baru. Mereka menunjukkan perilaku yang aneh, tidak memiliki strategi yang koheren, tidak terorganisir dalam mengatasi stress (Prior \& Glaser, 2006). Menurut Main \& Hesse (Prior \& Glaser, 2006), bahwa hal yang mendahlui terjadinya disorganized attachment adalah perilaku yang menakutkan dari figur kelekatannya. Selain ketakutan langsung kepada anak yang disebabkan oleh penganiayaan orang tua, dan pola perilaku orang tua yang tampaknya cenderung menakut-nakuti anak baik dengan mengancam secara langsung atau dengan menunjukkan ketakutan yang berasal dari orang tua.

Ketersediaan dan komunikasi menjadi hal yang diperhatikan dalam ikatan kelekatan ini.. Seringkali Remaja sulit berkomunikasi dengan orang tua mengenai masalah internalnya. Hal itu adalah sebuah keresahan yang dia simpan. Kesulitan dalam berkomunikasi ini biasanya berasal dari kurangnya kepekaan orang tua(Cassidy, 2016).

Ketika jalur komunikasi antara orang tua-anak dapat terbuka, peristiwa yang mengganggu dan menjadi konflik dapat didiskusikan dan ancaman yang dirasakan mengenai ketersediaan figur kelekatan dapat diputuskan. Dalam hubungan yang ditandai dengan ekpektasi keyakinan akan ketersediaan figur kelekatan, ancaman yang dirasakan seringkali akan menghasilkan sebuah percakapan yang menghasilkan sebuah kepercayaan dimana anak akan cenderung secara langsung mengungkapkan perasaan negatif yang dirasakan(Cassidy, 2016).

\section{Konseling Kelompok}

Layanan konseling kelompok merupakan sebuah layanan yang bersifat interventif dan berorientasi pada masalah yang para anggotanya sangat menentukan isi dan tujuan mereka (Rusmana, 2009). 
Konseling kelompok cenderung berorientasi pada pertumbuhan karena penekanannya pada menemukan sumber kekuatan internal. para anggota kelompok mungkin menghadapi krisis situasional dan konflik, berjuang dengan masalah-masalah kehidupan pribadi atau antarpribadi, mengalami kesulitan dengan transisi kehidupan, atau mencoba mengubah perubahan yang merusak diri sendiri (Corey, 2012).

Menurut Corey (2012), terdapat enam langkah dalam melaksanakan konseling kelompok. langkah-langkah tersebut yaitu:

Tahap Pembentukan; Tahap ini merupakan tahap dalam perencanaan atau perencanaan sebelum dilaksanakannya konseling kelompok.

Tahap Orientasi dan eksplorasi; Pada tahap orientasi dan eksplorasi, kegiatan kelompok dimulai dengan menentukan struktur grup, mengenalkan diri masingmasing, dan mengeksplorasi harapan dari para anggota kelompok.

Tahap transisi; Pada tahap ini, anggota kelompok berhadapan pada kecemasan, pembelaan diri, konflik dan ambivalensi mereka untuk berpartisipasi dalam kelompok. Tugas pemimpin kelompok adalah membantu anggota kelompok untuk mulai belajar agar bekerja dan merasa anggota diterima dengan anggota kelompok lainnya.

Tahap kegiatan; Pada tahap ini, pemimpin kelompok mengekslorasi lebih mendalam menenai masalah yang berkaitan dengan anggota kelompok dan tindakan yang efektif untuk menghasilkan perubahan perilaku yang diinginkan

Tahap konsolidasi dan terminasi; Tahap ini merupakan tahap menuju tahap akhir, dimana pemimpin kelompok membantu anggota kelompok untuk mentransfer apa yang telah mereka pelajari di dalam kelompok ke lingkungan luar mereka

Tahap Evaluasi dan tindak lanjut; Tahap ini merupakan tahap terakhir, namun tahap terakir bukan berarti bahwa tugas pemimpin kelompok sudah selesai, karena terdapat pertimbangan penting setelah pengakhiran, yaitu melihat keberhasilan penyelesaian pengembangan suatu kelompok lewat evaluasi dan tindak lanjut.

\section{Problem solving}

Menurut D'Zurilla \& Goldfried (1971), problem solving didefinisikan sebagai suatu proses perilaku dan kognitif yang menyediakan berbagai alternatif respon yang berpotensi efektif untuk menghadapi situasi yang bermasalah dan meningkatkan kemungkinan memilih respon yang paling efektif diantara berbagai alternatif. Tugas dalam problem solving ini menggabungkan respon-respon yang diperoleh sebelumnya dengan cara yang baru sehingga menghasilkan respon atau pola yang baru dan membentuk pola hubungan dan situasi bermasalah tertentu. Dalam hal ini problem solving mengacu pada proses atau teknik yang digunakan seseorang untuk menemukan solusi suatu masalah.

Menurut D'Zurilla \& Goldfried (1971), Terdapat empat penyelesaian masalah yang dirancang berorientasi demokratis untuk upaya pada resolusi sebuah konflik. Langkah-langkah tersebut yaitu:

Mendefinisikan masalah; Dalam mendefinisikan masalah, individu akan mengenali situasi yang mereka anggap bermasalah yang akan menghambat mereka untuk merespon secara otomatis merunurut dorongan hatinya.

Menghasilkan solusi alternatif; Tugas utama dalam tahap ini adalah menghasilkan solusi yang sesuai dengan situasi masalah tertentu, dan memaksimalkan kemungkinan respon yang paling efektif. Semakin banyak solusi yang dihasilkan, semakin banyak pula kemungkinan solusi tersebut akan berguna.

Pengambilan keputusan; Pada tahap ini, ketika individu menghasil solusi alternatif, kemungkinan besar individu akan memilih pilihan solusi dengan kualitas yang paling baik dan membawa kebaikan bagi dirinya. pengambilan keputusan dibuat berdasarkan nilai-nilai individu. Konsekuensi pun akan dihadapkan jika 
individu akan mengambil sebuah keputusan. Individu perlu memikirkan konsekuensi apa yang akan ia hadapi dalam pengambilan keputusan tersebut.

Implementasi perencanaan; Pada tahap terakhir, individu akan mengimplmentasikan solusi yang telah dipilih, individu diminta dengan hati-hati memonitor dan mengevaluasi hasil dari solusi yang dipilih setelah mencoba menerapkannya dalam situasi problematik dalam kehidupan nyata.

\section{METODE PENELITIAN}

Metode penelitian yang dilakukan dalam penelitian ini adalah metode eksperimen. Desain penelitian yang digunakan peneliti adalah Quasi Experimental dengan Pretest-Posttest Nonequivalent Control Grup Design. Kuasi experimen memiliki kelompok kontrol namun tidak dapat sepenuhnya mengontrol variable-variabel yang mempengaruhi pelaksanaan eksperimen (Sugiyono, 2016).

Populasi dalam penelitian adalah peserta didik kelas X di SMA Bina Dharma Jakarta Timur sebanyak 178 orang. Teknik pengambilan sampling yang akan peneliti gunakan adalah purposive sampling. Purposive sampling adalah teknik penentuan sampel dengan pertimbangan dan tujuan tertentu (Sugiyono, 2016). Maka dapat dipahamai bahwa teknik pengambilan sampling dengan purposive sampling berdasarkan tujuan, karakteristik, dan pertimbangan tertentu sesuai dengan tujuan peneliti.

Adapun karakteristik subjek di dalam penelitian ini adalah peserta didik SMA Bina Dharma yang memiliki skor yang tinggi dari instrumen adaptasi Relationship Styles Questionnarie (RSQ) yang dikembangkan oleh Griffin dan Kim Bartholomew untuk mengetahui peserta didik yang memiliki insecure attachment. Setelah didapat skor dari instrumen Relationship Styles Questionnarie (RSQ), Lalu peneliti akan memilih peserta didik kembali yang memiliki konflik dengan orang tua instrumen Issue Checklist yang dibuat oleh Arthur L Robin, lalu peneliti membagi peserta didik ke dalam dua kelompok. dua kelompok inilah yang akan dijadikan sampel oleh peneliti satu kelompok sebagai kelompok eksperimen, dan satu kelompok lainnya akan digunakan sebagai kelompok kontrol.

Teknik analisis data yang digunakan dalam penelitian ini adalah Mann Whitney U Test dengan menggunakan bantuan aplikasi SPSS 20.0 for Windows. Metode Mann Whitney U Test digunakan untuk menguji hipotesis komparatif dua sampel independen serta datanya berbentuk ordinal. (Sugiyono, 2017).

\section{HASIL PENELITIAN}

Berdasarkan hasil penyebaran instrumen Relationship Styles Questionnarie (RSQ) yang disebar kepada 161 peserta didik, didapatkan hasil terdapat 86 peserta didik yang memiliki insecure attachment yang tinggi. Dari 86 peserta didik, dipilih kembali 39 peserta didik dipilih kembali dengan menyebarkan instrumen issue checklist. Berdasarkan hasil issue checklist, didapatkan hasil terdapat 10 peserta didik yang memiliki skor intensitas konflik yang tinggi. Dari 10 peserta didik yang terpilih kemudian dibagi ke dalam 2 kelompok, 5 orang pada kelompok eksperimen dan 5 orang pada kelompok kontrol. Pembagian anggota kelompok eksperimen dan kontrol dilakukan secara random dengan membagikan 10 kertas pada 10 peserta didik yang bertuliskan angka 1-5 eksperimen dan angka 1-5 kontrol.

Adapun grafik hasil pretest dan posttest pada kelompok eksperimen dan kelompok kontrol adalah sebagai berikut: 


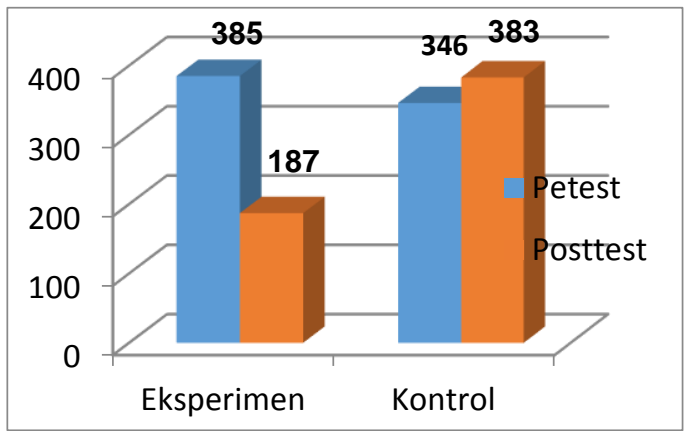

Grafik 1. Hasil Total Skor Pretest-Posstest Intensitas Konflik Kelompok Eksperimen dan Kelompok Kontrol

Berdasarkan jumlah skor pretest dan posttest intensitas konflik pada kelompok eksperimen dan kelompok kontrol, terlihat adanya perbedaan skor antar keduanya. Pada kelompok eksperimen memperoleh total skor sebesar 385 pada saat pretest, dan saat posttest memperoleh total skor sebesar 187 yang menujukkan bahwa terdapat penurunan total skor sebesar 198. Pada kelompok kontrol memperoleh total skor pretest sebesar 346, dan pada saat posttest memperoleh total skor sebesar 383 yang menunjukkan bahwa terdapat peningkatan total skor sebesar 37.

Selanjutnya adalah hasil pretest dan posttest per aspek pada kelompok eksperimen dan kelompok kontrol. Hasil tersebut data tersebut adalah sebagai berikut:

\begin{tabular}{ccccccccccc}
\hline \multirow{2}{*}{ Nama } & \multicolumn{3}{c}{ Aspek1 } & \multicolumn{3}{c}{ Aspek2 } & \multicolumn{3}{c}{ Aspek3 } & \multicolumn{3}{c}{ Aspek 4 } & \multicolumn{3}{c}{ Aspek5 } \\
\cline { 2 - 10 } & Pre & Post & Pre & Post & Pre & Post & Pre & Post & Pre & Post \\
\hline HWA & 15 & 7 & 30 & 16 & 4 & 3 & 13 & 7 & 8 & 3 \\
JWP & 14 & 8 & 27 & 15 & 5 & 4 & 10 & 5 & 3 & 2 \\
JA & 3 & 2 & 34 & 19 & 8 & 5 & 20 & 8 & 5 & 2 \\
DF & 13 & 8 & 51 & 22 & 8 & 6 & 21 & 7 & 6 & 3 \\
NZ & 16 & 8 & 33 & 16 & 10 & 4 & 22 & 7 & 6 & 2 \\
\hline Jumlah & 61 & 33 & 175 & 88 & 35 & 22 & 86 & 34 & 28 & 12 \\
\hline
\end{tabular}

Tabel 1. Skor Pretest dan Posttest Intensitas Konflik Per Aspek Kelompok Ekperimen

\begin{tabular}{ccccccccccc}
\hline \multirow{2}{*}{ Nama } & \multicolumn{2}{c}{ Aspek1 } & \multicolumn{3}{c}{ Aspek2 } & \multicolumn{3}{c}{ Aspek 3 } & \multicolumn{3}{c}{ Aspek 4 } & \multicolumn{3}{c}{ Aspek 5 } \\
\cline { 2 - 11 } & Pre & Post & Pre & Post & Pre & Post & Pre & Post & Pre & Post \\
\hline NQA & 11 & 11 & 37 & 40 & 9 & 9 & 13 & 13 & 7 & 7 \\
RDF & 9 & 9 & 20 & 23 & 7 & 7 & 11 & 11 & 15 & 15 \\
CM & 12 & 18 & 27 & 34 & 10 & 12 & 16 & 16 & 19 & 21 \\
ND & 9 & 12 & 26 & 27 & 5 & 7 & 12 & 13 & 6 & 7 \\
SA & 7 & 10 & 23 & 23 & 10 & 10 & 17 & 18 & 8 & 10 \\
\hline Jumlah & 48 & 60 & 133 & 147 & 41 & 45 & 69 & 71 & 55 & 60 \\
\hline
\end{tabular}

Tabel 2. Skor Pretest dan Posttest Intensitas Konflik Per Aspek Kelompok Kontrol

Keterangan:

Aspek 1 : Kehidupan Sosial

Aspek 2 : Tanggung Jawab

Aspek 3 : Sekolah

Aspek 4 : Hubungan Keluarga

Aspek 5 : Aturan Sosial

Berdasarkan data prestest dan posttest tersebut dapat disimpulkan bahwa pada kelomok eksperimen mengalami penurunan pada setiap aspek, sedangkan pada data pretest dan posttest pada kelompok kontrol terdapat beberapa aspek yang memiliki total skor tetap di setiap individunya dan terdapat pula yang meningkat di setiap aspeknya.

Adapun terdapat hasil pengolahan statistik antara kelompok eksperimen dan kelompok kontrol menggunakan rumus Mann Whitney U Test berdasarkan gain score. Berdasarkan hasil tersebut Nampak bahwa skor Mann-Whitney $U=0,000$, nilai $\mathrm{Z}=-2,619$, dan Asymp.sig (1-tailed) sebesar 0,008 . Nilai probabilitas tersebut lebih kecil dibandingkan nilai signifikansi $\alpha$ (alpha) 0,05 yang digunakan dalam penelitian ini. Dengan demikian dapat dinyatakan bahwa $\mathrm{H} 0$ ditolak dan $\mathrm{H} 1$ diterima.

Berdasarkan hasil pengujian hipotesis didapatkan bahwa konseling kelompok dengan teknik problem solving memberikan pengaruh yang signifikan dalam menurunkan skor intensitas konflik antara remaja yang memiliki insecure attachment dengan orang tua. Dengan adanya hasil ini, maka tujuan penelitian yang telah dipaparkan pada bab sebelumnya yaitu untuk melihat pengaruh dari penerapan layanan konseling kelompok dengan teknik 
problem solving pada remaja yang memiliki insecure attachment dengan orang tua dapat dicapai.

Hasil ini juga dapat disimpulkan bahwa kelompok eksperimen memiliki penurunan skor intensitas konflik lebih besar daripada kelompok kontrol. Hasil ini menunjukkan bahwa pelaksanaan layanan konseling kelompok dengan teknik problem solving dapat memberikan pengaruh yang signifikan terhadap penurunan skor intensitas konflik pada kelompok eksperimen dibandingkan dengan kelompok kontrol yang tidak mendapatkan layanan konseling kelompok dengan teknik problem solving.

Berdasarkan hasil pelaksanaan konseling kelompok dalam penelitian ini diketahui bahwa sebagian orang tua mereka memiliki tekanan emosi yang tinggi ketika berkonflik dengan anaknya, sehinga anggota kelompok pun merespon dengan perkataan yang tidak sopan pula. Hal ini pula yang mengakibatkan sulitnya anggota kelompok sulit untuk berkomunikasi dengan orang tuanya.

Selama proses pelaksanaan layanan konseling kelompok dengan teknik problem solving, terlihat adanya komunikasi yang terganggu antara anggota kelompok dengan orang tuanya karena mereka cenderung membiarkan konflik berlarut-larut dan menghindar. Hal ini yang menimbulkan konflik antara keduanya tidak dapat diatasi dengan baik. Oleh karena itu peneliti membuat suatu latihan untuk mengajarkan anggota kelompok dapat berkomunikasi dan berdiskusi secara baik dengan orang tua untuk mengatasi permasalahan yang terjadi diantara keduanya.

Hal ini dilakukan sebelum anggota kelompok mengimplementasikan perencanaan yang sudah dibuat. Latihan yang dibuat adalah dengan mengajarkan anggota kelompok untuk duduk berdua dan berdiskusi mengenai permasalahan yang terjadi antara dirinya dan orang tua. Anggota kelompok diminta untuk mengekspresikan dan mengungkapkan perasaan-perasaan apa yang selama ini dirasakan dirinya ketika mengalami konflik. Anggota kelompok diminta untuk menjelaskan dan mengevaluasi bagaimana seharusnya perilaku yang harus diperbaiki agar masalah terselesaikan.

Hal ini berdampak positif setelah anggota kelompok mengimplementasikan perencanaan yang sudah ia buat untuk dilakukan kepada orang tuanya. Dalam pengimplementasiannya, anggota kelompok mencoba membuka komunikasi agar mampu berdiskusi dengan menurunkan emosi dan ego masing-masing.

Langkah-langkah dalam pelaksanaan konseling kelompok disesuaikan dengan tahapan pada problem solving dimana dalam tahapan-tahapan tersebut terdapat penjelasan disetiap tahapannya.

Berdasarkan hasil kepuasan dalam pelaksanaan konseling kelompok, anggota kelompok merasa puas dan senang dengan kegiatan konseling kelompok. Hal ini menjadi salah satu faktor keberhasilan pencapaian tujuan konseling kelompok dimana anggota kelompok memiliki ketertarikan dalam pelaksaannya.. Dengan demikian, hasil penelitian menunjukkan bahwa penerapan konseling kelompok dengan teknik problem solving diterima dengan antusias yang sangat baik oleh peserta didik atau remaja yang memiliki insecure attachment dengan orang tua.

Adapun keterbatasan dalam penelitian ini antara lain: (1) Peneliti tidak menggunakan rumus mean teoritik dalam membuat kategorisasi penelitian; (2) Dalam proses penyaringan data, banyak peserta didik yang tidak hadir sehingga tidak semua peserta didik dapat mengisi instrumen untuk keperluan data peneliti; (3) Waktu yang dilakukan dari melakukan validitas hingga posttest memakan waktu yang cukup lama sehingga dianggap tidak efisien waktu; (4). Dalam pelaksanaan penelitian ini, konseling kelompok dilakukan oleh peneliti sendiri tanpa dibantu oleh ahli yang telah menguasai teknik Problem solving, sehingga memungkinkan dapat menurunkan ketercapaian tujuan konseling kelompok; (5) 
Pelaksanaan konseling kelompok dilakukan dengan jangka waktu hanya seminggu, walaupun dalam perencanaan dilakukan sebanyak 9 sesi, peneliti memadatkan menjadi sehari menjadi 1-2 sesi.

\section{KESIMPULAN}

Berdasarkan hasil penelitian dan pembahasan mengenai pengaruh konseling kelompok dengan teknik problem solving untuk mengatasi konflik antara remaja yang memiliki insecure attachment dengan orang tua, maka diperoleh kesimpulan sebagai berikut:

1. Berdasarkan hasil pengolahan data pretest sebelum pelaksanaan eksperimen, diperoleh data bahwa 5 orang anggota kelompok eksperimen berada pada kategori tinggi

2. Berdasarkan hasil pengolahan data posttest setelah pelaksanaan ekperimen, diperoleh data bahwa 4 orang berada pada kategori rendah dan 1 orang berada pada kategori sedang.

3. Berdasarkan deskripsi data tersebut, maka didapatkan hasil bahwa secara keseluruhan anggota kelompok yang mendapatkan konseling kelompok dengan teknik problem solving yang berada pada kategori sedang dan rendah memiliki penurunan skor intensitas konflik.

4. Berdasarkan hasil pengujian hipotesis yang dilakukan dengan menggunakan Mann Whitney U Test pada data gain score kelompok eksperimen dan kelompok kontrol didapatkan hasil yaitu mendapat nilai signifikasi sebesar 0,008 $<0,05$ yang berarti bahwa konseling kelompok dengan teknik problem solving berpengaruh secara signifikan terhadap level konflik pada remaja yang memiliki insecure attachment dengan orang tua.

5. Berdasarkan hasil pengujian hipotesis juga menunjukkan bahwa pelaksanaan layanan konseling kelompok dengan teknik problem solving dapat memberikan dampak yang signifikan terhadap penurunan skor intensitas konflik pada kelompok eksperimen dibandingkan dengan kelompok kontrol yang tidak mendapatkan layanan konseling kelompok dengan teknik problem solving.

\section{SARAN}

Adapun saran yang dapat menjadi pertimbangan berdasarkan hasil penelitian ini yaitu: (1) Bagi guru bimbingan konseling di sekolah, disarankan untuk dapat memberikan layanan konseling kelompok kepada para peserta didik untuk membantu permasalahan mereka di sekolah maupun dirumah, terutama mengenai konflik yang terjadi antara peserta didik dan orang tua dirumah, dan juga agar peserta didik lebih mengenal dan mengetahui layanan konseling kelompok; (2) Bagi mahasiswa, penelitian ini dapat dijadikan bahan referensi yang berhubungan dengan kegiatan konseling kelompok, problem solving, konflik orang tua-remaja, dan juga attachment; (3) Bagi peneliti lain yang ingin mengembangkan penelitian yang serupa, sebaiknya peneliti memperkaya sumber bacaan atau referensi baik mengenai teori attachment, konflik, problem solving, dan teori konseling kelompok dan proses konselingnya.

\section{DAFTAR PUSTAKA}

Cassidy, J. (2016). The Nature of the Child's Ties. In J. Cassidy \& P. R. Shaver (Eds.), Handbook Of Attachment: Theory, Research, And Clinical Applications (3rd ed.). New York: Guilford Press.

Chatjoulis, A., \& Humphreys, P. (2007). A Problem Solving Process Model for Personal Decision Support (PSPMDS). Journal of Decision Systems, 16(2), 213-239. https://doi.org/10.3166/jds.16.213-239

Corey, G. (2012). Theory and practice of group counseling (8th ed.). Belmont, CA: Brooks/Cole.

D'Zurilla, T. J., \& Goldfried, M. R. (1971). Problem solving and behavior 
modification. Journal of Abnormal Psychology, 78(1), 107-126. https://doi.org/10.1037/h0031360

Hughes, D., Bomber, L. M., \& Brisch, K. H., \& Perry, A. (2009). Helping Adolescents Engage with Life and Learning. Worth Publishing.

Jaffee, W. B., \& D'Zurilla, T. J. (2003). Adolescent problem solving, parent problem solving, and externalizing behavior in adolescents. Behavior Therapy, 34(3), 295-311. https://doi.org/10.1016/S00057894(03)80002-3

Meichenbaum, D. L., Fabiano, G. A., \& Fincham, F. (2002). Communication in relationship with adolescent. In F. W. Kaslow \& T. Patterson (Eds.), Comprehensive Handbook of Psychotherapy, Cognitive-Behavioral Approaches (pp. 167-187). New Jersey: John Wiley \& Sons.

Ningsih, A. D. (2012). Pengelolaan Konflik Orang Tua-Remaja Dalam Keluarga Jawa. Surakarta: Universitas Muhammadiyah Surakarta.

Prior, V., \& Glaser, D. (2006). Understanding attachment and attachment disorders: Theory, evidence and practice. London: Jessica Kingsley Publishers.

Rice, F. P., \& Dolgin, K. G. (2005). The adolescent: Development, relationships and culture (11th ed.). Auckland, New Zealand: Pearson Education New Zealand.

Robin, A. L., \& Foster, S. L. (1989). The Guilford family therapy series. Negotiating parent-adolescent conflict: A behavioral-family systems approach. New York: Guilford Press.

Rusmana, N. (2009). Bimbingan dan Konseling Kelompok di Sekolah (Metode, Teknik, dan Aplikasi). Bandung: Rizqi Press.

Santrock, J. W. (2011). Life Span Development (5th ed.). Jakarta: Erlangga.

Sillars, A., Smith, T., \& Koerner, A. (2010). Misattributions contributing to empathic (in)accuracy during parentadolescent conflict discussions. Journal of Social and Personal Relationships, 27(6), 727-747. https://doi.org/10.1177/026540751037 3261

Sugiyono. (2016). Memahami Penelitian Kualitatif. Bandung: Alfabeta. 